\title{
THE DESIGN AND IMPLEMENTATION OF A TEACHER TRAINING PROGRAM FOR IMPROVING TEACHERS' DISASTER LITERACY: INTERDISCIPLINARY DISASTER EDUCATION PROGRAM (IDEP)
}

\author{
Ayşegül Şeyihoğlu \\ Trabzon University, Turkey \\ E-mail: aseyihoglu@trabzon.edu.tr
}

Ayça Kartal

Muş Alparslan University, Turkey

E-mail: a.kartal@alparslan.edu.tr

\author{
Ahmet Tekbiyik \\ Kahramanmaras Sutcu Imam University, Turkey \\ E-mail: atekbiyik@gmail.com \\ Gülşah Sezen Vekli \\ Yozgat Bozok University, Turkey \\ E-mail: gulsahsezen28@gmail.com \\ Kader Birinci Konur \\ Recep Tayyip Erdogan University, Turkey \\ E-mail: kader.konur@erdogan.edu.tr
}

\begin{abstract}
The interdisciplinary aspect of natural disasters requires their correlation with more than one discipline and orientation for understanding and teaching the inevitable nature of disasters. This study aimed to design a teacher training program called the Interdisciplinary Disaster Education Program (IDEP) and reveal its effect on improving teachers' natural disaster literacy. Furthermore, teachers' opinions about program were examined. The mixed-method design was used in the study. The study participants consisted of 36 teachers (science, classroom, and social studies teachers) working on different subjects. Data were obtained using the Natural Disaster Literacy Scale and the survey for the IDEP. The data collected from the scale were analyzed using two-way mixed ANOVA. The qualitative data collected from the survey were subjected to content analysis. The results indicated that the IDEP statistically improved teachers' natural disaster literacy. Moreover, the survey results highlighted that different instructional activities (experiments, modeling, workshops, rock/soil analysis, coding, augmented reality, and STEM applications, etc.) related to natural disasters contributed to a lot of professional and personal knowledge of teachers, particularly disaster management.
\end{abstract}

Keywords: disaster literacy, interdisciplinary education, mixed method, natural disaster, teacher training program 
Ayşegül ŞEYIHOĞLU, Ayça KARTAL, Ahmet TEKBIYIK, Gülşah SEZEN VEKLI, Kader BIRINCI KONUR. The design and implementation of a teacher training program for improving teachers' disaster literacy: Interdisciplinary disaster education program (IDEP)

PROBLEMS

OF EDUCATION IN THE $21^{\text {st }}$ CENTURY Vol. 79 , No. 5, 2021

782

\section{Introduction}

According to the data of the World Disasters Report 2020, more than 100 disasters occurred in the first six months of the year, and more than 50 million people were affected by these disasters (IFRC, 2020:17). Upon examining the source of the disasters mentioned in this report, it is observed that natural disasters with the air and ground origin come to the fore. Natural disasters with the source from the sun (avalanche, flood, storm, etc.) or the Earth (volcanism, earthquake, tsunami, etc.) are situations that require people to be prepared (Ünal, 2019). The fact that this preparation covers all areas of human interest, family, school, workplace, public institutions and organizations, etc. reveals the necessity for society to acquire natural disaster literacy through natural disaster education.

Disaster literacy was addressed for the first time within the framework of health literacy by Brown et al. (2014) with the expression "disaster literacy" and was expressed as a late concept essentially defined by its role in health and safety. Chung and Yen (2016) indicated three dimensions within the scope of disaster prevention literacy: information (disaster information, disaster prevention and preparedness information, rescue-response, and participation information), attitude (disaster prevention awareness, disaster prevention values, disaster prevention sense of responsibility), behavior (disaster preparedness action, disaster response behaviors).

There are hydrometeorological, climatological, geophysical, and biological factors in the occurrence of natural disasters. "Natural disasters have effects and causes in close relation with the socio-economic development, demographic and industrial status of communities" (MataLima et al., 2013, p. 47). Mostly, multiple disciplines need to be associated with each other to solve problems caused by disasters (Faber et al., 2014). Here, there is a link between natural disasters and disciplines such as architecture, engineering, geometry, geophysics, geology, anthropology, and sociology.

A paradigmatic change has been observed in the attitude of the global community toward natural hazards. Communities have turned from a rescue-based approach to a holistic approach that requires preventing and reducing events and being prepared for disasters (Das, 2011). Studies have emphasized the necessity of addressing natural disasters with a holistic approach (Taubenbock et al., 2009). Another study emphasized the integration of health education to reduce the risk of disasters (Pascapurnama et al., 2018). The interdisciplinary approach, which is defined as examining a situation, phenomenon, or event by bringing together at least two disciplines or subject areas (Jacobs, 1989), is predicted to enable people to live more consciously in society and their natural environments (Miller, 2005). Therefore, the interdisciplinary aspect of natural disasters requires their correlation with more than one discipline and orientation for understanding and teaching the inevitable nature of disasters.

\section{Literature Review}

In the literature, studies on natural disasters in the field of social sciences focus on disaster education (de Mendonca \& Valois, 2017; Lin et al., 2018; Nifa et al., 2017; Panić et al., 2013; Sözcü, 2020) and disaster literacy (Çalışkan, 2020; Kimura et al., 2017; Priyowidodo \& Luik, 2013; Sözcü \& Aydınözü, 2019). Some studies on disaster education address the aforementioned interdisciplinary approach. Jones et al. (2012) conducted a study on the development of a program for disaster risk education with an interdisciplinary approach among different units of a university, and this study emphasized the importance of sharing experiences in disasters, particularly in addition to bringing together academic specialists.

In the study conducted with primary and lower secondary school students and their teachers (Zhu \& Zhang, 2017), students expressed the need to strengthen school disaster 
Ayşegül ŞEYIHOĞLU, Ayça KARTAL, Ahmet TEKBIYIK, Gülşah SEZEN VEKLI, Kader BIRINCI KONUR. The design and implementation of a teacher training program for improving teachers' disaster literacy: Interdisciplinary disaster education program (IDEP)

education. In support of this study, studies on reducing the disaster risk mentioned that education should be used as an effective tool (Baytiyeh, 2017; Cabilao-Valencia et al., 2018; Sözcü, 2019; Vaughter, 2016).

The study on implementing the school-based disaster education program for teachers (Gökmenoğlu et al., 2020) asserted that the disaster awareness of teachers was enhanced after this training, there were changes in their behaviors toward disasters, and their levels of knowledge on disasters increased. Studies on disaster risk education were carried out with teachers and students in primary and lower secondary school curricula in thirty different countries (Selby \& Kagawa, 2012), and the need for affective learning in disaster education increased further since it indicated that pre-disaster learning gained more importance than post-disaster learning along with the increase in the number of disasters. Another study revealed that female science teachers found the topics about disaster education more meaningful than male teachers. Teachers stated that no adequate learning settings (materials, books, sources etc.) could be provided for disaster education, which was their most significant problem, and suggested the possibility of effective disaster education through schools as the solution (Buluş-Kırıkkaya et al., 2011b). A study suggested that the knowledge dimension was often examined in disaster education studies, and there was a need for studies on the implementation and planning dimensions (Koç et al., 2020).

Studies on improving the disaster literacy of society were reviewed in different dimensions such as disaster information literacy (Mustadi \& Atmojo, 2020; Sözcü \& Aydınözü, 2019), disaster prevention literacy (Rahim \& Wu, 2015), disaster literacy (Sampurna et al., 2015), disaster risk reduction literacy (Kanbara et al., 2016), disaster damage reduction literacy (Priyowidodo \& Luik, 2013), and disaster management literacy (Kimura et al., 2017). Here, it can be suggested that behavioral and affective tendency dimensions particularly come to the fore in disaster education.

Natural disasters create psychological reactions such as depression and anxiety in individuals and have behavioral and affective effects such as academic achievement, substance use, suicidal ideation, anxiety disorders, etc. (Karabulut \& Bekler, 2019; Türkan \& K1lıç, 2017). Differences, especially in these affective and behavioral dimensions, possibly result from demographic variables such as age, gender, social status, etc. (Neumayer \& Plümper, 2007; Okay \& İlkkaracan, 2018).

\section{Disaster Literacy and Gender}

The contribution of women's genetic and physiological differences/characteristics and skills to disaster relief has started to be admitted after the latest large-scale disasters and urban earthquakes. These can be summarized as an adaptation to the rehabilitation period of disaster management and resilience, risk perception, versatility and ability to observe and evaluate details, the ability to resist a psychological trauma, natural ability for group therapy, competency in search and rescue, and performance in non-governmental organizations (Iş1k et al., 2015). The group that constitutes the majority of society including "women, children, the elderly and disabled should be studied separately and included in the disaster management system according to the 2012-2023 National Earthquake Strategy and Action Plan by AFAD (Disaster and Emergency Management Presidency of Turkey). The ability to cope with disasters should be enhanced, helplessness should be reduced, and social bonds should be strengthened." In this process, gender has been considered a factor that increases helplessness. While women are in the high-risk group in affective and behavioral dimensions regarding disaster literacy, they may also represent significant human resources for the rehabilitation process following a disaster. At the 3rd International Workshop on Gender and Disasters (Pincha, 2009) and the Fourth World Conference on Women Platform, the United Nations Beijing Declaration (UN Beijing Declaration, 1995) constituted a significant source of literature for studies that revealed
PROBLEMS

OF EDUCATION

IN THE $21^{\text {st }}$ CENTURY

Vol. 79, No. 5, 2021 
Ayşegül ŞEYIHOĞLU, Ayça KARTAL, Ahmet TEKBIYIK, Gülşah SEZEN VEKLI, Kader BIRINCI KONUR. The design and implementation of a teacher training program for improving teachers' disaster literacy: Interdisciplinary disaster education program (IDEP)

PROBLEMS

OF EDUCATION

IN THE $21^{\text {st }}$ CENTURY Vol. 79 , No. 5, 2021

784

the effects of natural disasters on women. Therefore, it was needed to evaluate disaster literacy levels regarding the gender variable within the scope of the study's problem statement (Okay \& İlkkaracan, 2018).

\section{Disaster Literacy and Branch}

In the literature, it is stated that effective disaster education can prevent or reduce the effects of some disasters, people with disaster education can protect themselves and others in a better way, and comprehensive education programs should be planned and designed for those who are faced with disasters (Torani et al., 2019). In the study conducted by Johnson and Ronan (2014), including the facilitation of peer guidance among teachers via schools, suggestions were made on supporting the significant roles of teachers in disasters. Moreover, in this study, it is stated that it will be useful if teachers have more knowledge to provide students with emotional support and disaster-sensitive disaster education after disasters in society. Considering that the learning process is more successful with experience-based and practical studies, it is indicated that effective disaster education activities should be based on holistic learning covering all the phenomena, experiences, and culture in cooperation with local communities and schools (Nifa et al., 2017).

The awareness of the branches of different disasters is observed to be at different levels. For example, primary teachers may have a high awareness of some types of disasters (Akbulut $\&$ Kaya, 2020). The perceptions of prospective teachers from different branches, for example, prospective geography teachers, prospective social studies (Yazıcı \& Ulu-Kalın, 2018) teachers or prospective classroom (Değirmenci, 2019) teachers regarding the concept of disaster may differ. The fallacies of teachers or prospective teachers on the subject also differ by branch (Cin, 2010; Öcal et al., 2016). Therefore, the branch of the participating teachers was one of the independent variables in this study.

Based on this information, it can be said that the literature, which will lay the ground for the development of the affective and behavioral dimensions of disaster literacy with teachers from different branches, investigates the gender variable and will form a basis for interdisciplinary disaster education, is limited. Along with these limitations, no teacher training created with interdisciplinary activities related no natural disasters was encountered in the literature. This study, which is designed with an interdisciplinary perspective and activities that support the structure of natural disasters by integrating especially positive sciences (physics, chemistry, biology, mathematics, etc.) and social sciences (drama, music, art, history, geography), differs from other studies in the literature with this aspect. At this point, it is predicted that the interdisciplinary disaster education aiming to provide disaster literacy will contribute to the literature.

\section{Research Questions}

This study attempted to determine the effect of the natural disaster teacher training program designed with the interdisciplinary approach on improving teachers' natural disaster literacy. In this context, answers to the following questions were sought.

1. What is the effect of the IDEP on teachers' natural disaster literacy (with the behavioral/affective tendency dimensions)?

1a. Does the improvement of teachers' natural disaster literacy during the IDEP differ by gender?

1b. Does the improvement of teachers' natural disaster literacy during the IDEP differ by branch?

2. What are the teachers' expectations regarding IDEP, and to what extent are those expectations met? 
Ayşegül ŞEYIHOĞLU, Ayça KARTAL, Ahmet TEKBIYIK, Gülşah SEZEN VEKLI, Kader BIRINCI KONUR. The design and implementation of a teacher training program for improving teachers' disaster literacy: Interdisciplinary disaster education program (IDEP)

\section{Research Methodology}

In this study, "the embedded mixed design" was used. The embedded mixed design emerges when the researcher collects and analyzes data in conventional quantitative and qualitative designs (Creswell \& Plano Clark, 2015). The interdisciplinary disaster education teacher training program was prepared to improve natural disaster literacy at the first stage of the study (See Figure 1).

\section{Figure1}

The Embedded Mixed Design Used in the Study

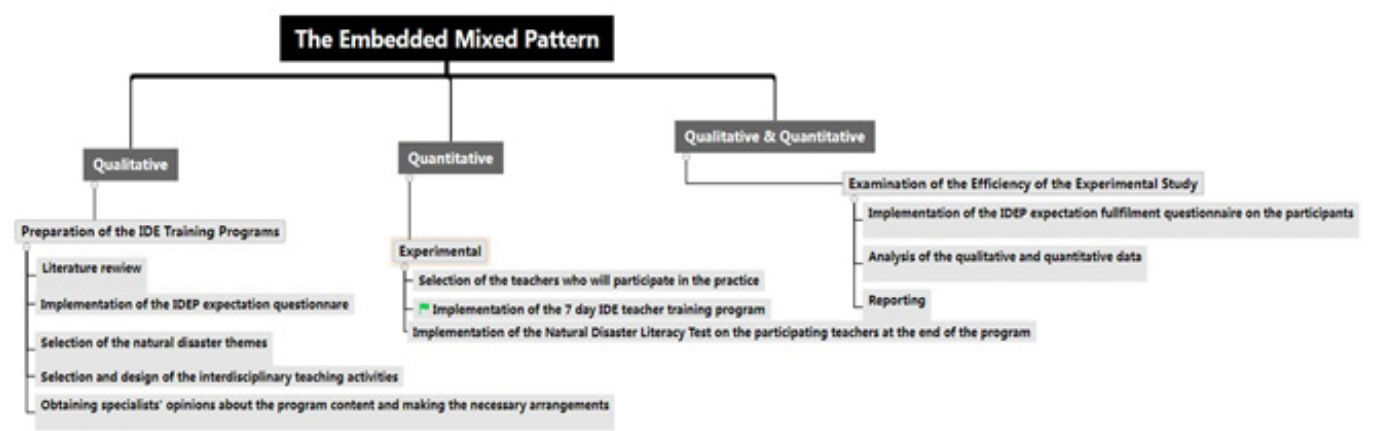

The literature on natural disaster literacy and interdisciplinary teaching was reviewed in the preparation process, and teachers' expectations about the program were determined using the IDEP expectation questionnaire. In light of these data, the natural disaster themes of the 7-day program were specified, and interdisciplinary teaching activities were designed for these themes. The opinions of specialists in the subject were received about the program content, and the program was finalized after making the necessary arrangements. In the experimental study process, the second stage of the study, the prepared IDEP was applied to 36 participants for 7 days. In the experimental study process, the teachers who would attend the program were first determined, and the natural disaster literacy test was applied as the pre-test to identify their current natural disaster literacy levels. Afterward, the IDEP was applied to 36 participants for 6 days by educators specialized in the IDEP. At this stage, conducted in the single-group experimental design, the natural disaster literacy test was applied to teachers as the post-test at the end of the program. At the third stage, the efficiency of the experimental study was checked. The data obtained from the quantitative and qualitative data collection tools were analyzed and examined within the scope of the research questions, and the results were reported. All stage of this research was done between 30.08.2020-17.02.2021.

\section{Participants}

The subject of natural disasters in primary and lower secondary school curricula is addressed at different levels and in different aspects within the scope of the Science, Social Studies and Life Sciences courses. In this respect, the target mass of the program is science, social studies, and classroom teachers working in state schools across Turkey. Of the 112 teachers who applied for the program voluntarily by filling in the application form on the program's website, 36 were accepted to the program as participants. The study group was determined as 36 people within the framework of the restrictions imposed by the COVID-19 conditions. Within the framework of the conditions allowed by these restrictions, it was aimed that the selected study group would provide diversity in different teacher branches. Therefore, the prepared activities 
Ayşegül ŞEYIHOĞLU, Ayça KARTAL, Ahmet TEKBIYIK, Gülşah SEZEN VEKLI, Kader BIRINCI KONUR. The design and implementation of a teacher training program for improving teachers' disaster literacy: Interdisciplinary disaster education program (IDEP)

OF EDUCATION

IN THE $21^{\text {st }}$ CENTURY Vol. 79, No. 5, 202

were designed for 6 groups of 6 people, and 36 teachers participated in the program. While selecting teachers, criteria such as being social studies, science or classroom teachers, not having attended a similar training program before, being highly motivated and willing, and not having any severe health problems were met. The information about the participants was obtained from the section of personal information in the application form and summarized in Table 1 below.

Table 1

Demographic Distribution of the Teachers Participating in the IDEP

\begin{tabular}{|c|c|c|c|c|c|}
\hline Variables & Groups & $\%$ & Variables & Groups & $\%$ \\
\hline \multirow{2}{*}{ Gender } & Female & 51.4 & \multirow{3}{*}{$\begin{array}{l}\text { Status of taking } \\
\text { training on natural } \\
\text { disasters }\end{array}$} & Yec & \multirow{2}{*}{51.4} \\
\hline & Male & 48.8 & & 100 & \\
\hline \multirow{3}{*}{ Subject } & Science & 33.3 & & No & 48.6 \\
\hline & Social studies & 33.3 & \multirow{5}{*}{$\begin{array}{l}\text { Natural disaster } \\
\text { potential risk of their } \\
\text { residence }\end{array}$} & Very low risk & 2.9 \\
\hline & Classroom & 33.3 & & Low risk & 25.7 \\
\hline \multirow{5}{*}{ Experience } & $1-5$ years & 17.1 & & Moderate risk & 42.9 \\
\hline & $6-10$ years & 25.7 & & High risk & 8.6 \\
\hline & $11-15$ years & 25.7 & & Very high risk & 20 \\
\hline & $16-20$ years & 25.7 & \multirow{3}{*}{$\begin{array}{l}\text { Status of taking } \\
\text { emergency } \\
\text { education on natural } \\
\text { disasters }\end{array}$} & \multirow[b]{2}{*}{ Yes } & \multirow[b]{2}{*}{62.9} \\
\hline & $\begin{array}{l}21 \text { and more } \\
\text { years }\end{array}$ & 10.8 & & & \\
\hline \multirow{3}{*}{ Educational status of teachers } & $\begin{array}{l}\text { Bachelor's } \\
\text { degree }\end{array}$ & 68.6 & & No & 37.1 \\
\hline & Master's degree & 28.6 & \multirow{2}{*}{$\begin{array}{l}\text { Status of their } \\
\text { experiencing natural } \\
\text { disasters }\end{array}$} & Yes & 40 \\
\hline & Ph.D. degree & 2.7 & & No & 60 \\
\hline
\end{tabular}

\section{Data Collection Tools}

In the study, the Natural Disaster Literacy Behavior Scale and the Natural Disaster Literacy Affective Tendency Scale were used as data collection tools. Accordingly, changes in the teachers' behavioral and affective tendencies in relation to natural disasters were revealed with the pre-test-post-test application. Additionally, to determine teachers' expectations about the IDEP and the status of meeting their expectations, the IDEP expectation and expectation fulfillment questionnaires were used. The expectation questionnaire was applied to the teachers before the IDEP, and the expectation fulfillment questionnaire was applied after the training program. The research questions and the data collection tools used to find answers to these questions are summarized in Table 2. 
Ayşegül ŞEYIHOĞLU, Ayça KARTAL, Ahmet TEKBIYIK, Gülşah SEZEN VEKLI, Kader BIRINCI KONUR. The design and implementation of a teacher training program for improving teachers' disaster literacy: Interdisciplinary disaster education program (IDEP)

Table 2

The Data Collection Tools Used, Concerning the Research Questions

\begin{tabular}{|c|c|c|}
\hline No & Research Questions & Data Collection Tools \\
\hline 1 & $\begin{array}{l}\text { What is the effect of the IDEP on teachers' } \\
\text { natural disaster literacy (with the behavioral/ } \\
\text { affective tendency dimensions)? }\end{array}$ & $\begin{array}{l}\text { Natural Disaster Literacy Behavior Scale } \\
\text { Natural Disaster Literacy Affective Tendency Scale } \\
\text { IDEP Expectation Fulfillment Questionnaire }\end{array}$ \\
\hline $1 a$ & $\begin{array}{l}\text { Does the improvement of teachers' natural } \\
\text { disaster literacy during the IDEP differ by } \\
\text { gender? }\end{array}$ & \multirow{2}{*}{$\begin{array}{l}\text { Natural Disaster Literacy Behavior Scale } \\
\text { Natural Disaster Literacy Affective Tendency Scale } \\
\text { Personal Information Form }\end{array}$} \\
\hline $1 b$ & $\begin{array}{l}\text { Does the improvement of teachers' natural } \\
\text { disaster literacy during the IDEP differ by } \\
\text { branch? }\end{array}$ & \\
\hline 2 & $\begin{array}{l}\text { What are the expectations of teachers regarding } \\
\text { the IDEP and the status of meeting their } \\
\text { expectations? }\end{array}$ & $\begin{array}{l}\text { IDEP Expectation Questionnaire } \\
\text { IDEP Expectation Fulfillment Questionnaire }\end{array}$ \\
\hline
\end{tabular}

Natural Disaster Literacy Behavior Scale

This scale was developed by Sözcü (2019) to determine prospective teachers' behaviors toward natural disasters. It is important for individuals to be informed about and have attitudes toward natural disasters in order to have natural disaster literacy. However, more importantly, individuals need to turn their knowledge and attitudes into behaviors. All the knowledge and attitudes that do not turn into behaviors will be missing for natural disaster literacy. Although the scale used is for teacher candidates, the author has written permission that it will be used with teachers as well. There is also a master's thesis in which this scale is used on teachers (Demirdelen, 2018). For this reason, it was deemed appropriate to apply this scale to teachers in the study.

The Natural Disaster Literacy Behavior Scale consists of twenty-three 5-point Likerttype items (always, mostly, sometimes, rarely, never). Sixteen items have positive statements, and seven items have negative statements. Accordingly, the lowest score to be received from the scale is 23 , and the highest score is 115 . The questionnaire items were created within the framework of geographical search, personal protection measures, and physical and ideal approach themes. Cronbach's alpha reliability value of the Natural Disaster Behavior Scale was found to be 0.87 . This value shows that this scale is reliable and supports a single-dimensional measurement.

\section{Natural Disaster Literacy Affective Tendency Scale}

The awareness of individuals of what to do to prevent the damage caused by natural disasters and their affective tendency toward it constitute a significant dimension of disaster literacy. To determine the effect of the teacher training program on the affective tendency of teachers concerning natural disaster literacy, the "Natural Disaster Literacy Affective Tendency Scale" developed by Sözcü (2019) was used. 
Ayşegül ŞEYIHOĞLU, Ayça KARTAL, Ahmet TEKBIYIK, Gülşah SEZEN VEKLI, Kader BIRINCI KONUR. The design and implementation of a teacher training program for improving teachers' disaster literacy: Interdisciplinary disaster education program (IDEP)

PROBLEMS

OF EDUCATION IN THE $21^{\text {st }}$ CENTURY Vol. 79 , No. 5, 2021

788

The scale consists of twenty-five 5-point Likert-type items (I strongly agree, I agree, I am not sure, I disagree, I strongly disagree). Of the scale items, 9 include negative statements, and 16 include positive statements. Accordingly, the lowest score to be received from the scale is' 25 ,' and the highest score is ' 125 .' The questionnaire items were developed within the framework of the sensitivity, consciousness, individual and social preparation themes. Cronbach's alpha reliability value of the Natural Disaster Literacy Affective Tendency Scale was found to be 0.81 . This value shows that the scale is reliable and supports a single-dimensional measurement.

\section{IDEP Expectation Questionnaire and Expectation Fulfillment Questionnaire}

The IDEP expectation questionnaire was developed to determine teachers' expectations from the training program in the dimensions of knowledge/skills, activity types, and activity application areas. The open-ended questions in the questionnaire were examined by five academic members, specialists in the domain, and necessary arrangements were made. In the first section of the questionnaire, instructions containing information about the purpose of the survey, the purpose the data would be used for, etc. were presented to the teachers. In the second section, the survey questions were stated. This questionnaire was applied at the initial stage of the program. At the final stage of the program, the Expectation Fulfillment Questionnaire was used to determine at what level these expectations were met. The questions of this survey were created in parallel with the questions of the initial questionnaire (See Appendix).

\section{Designing the IDEP}

The purpose of the IDEP is to raise awareness of natural disasters and interdisciplinary disaster education in teachers and to increase teachers' levels of literacy on natural disasters. To achieve these goals, activities related to natural disasters in the program were designed to include different activities such as cooperative learning, inquiry, experiment, modeling, workshop practices, land trips, rock/soil analyses, drama, coding, and STEM from an interdisciplinary perspective.

There are a total of 31 different activities in the IDEP. In these activities, disasters such as earthquakes, floods, deluges, overflows, landslides and erosions with a regionally high risk potential were included. In the 7-day program content, an emphasis was laid upon the affective dimension of natural disaster literacy on the first day. To this end, officials from AFAD (Disaster and Emergency Management Presidency) (Şeyihoğlu \& Duman, 2019), which runs search and rescue activities and is affiliated to the Ministry of Internal Affairs, and UMKE (National Medical Rescue Team) institutions affiliated to the Ministry of Health, trained personnel and volunteers shared their personal experiences from some natural disasters in Turkey and their response moments in this process by supporting them with real photographs and videos. The introduction of the duties, authorities, and equipment over real events related to these institutions, which were engaged in the search, rescue, and first response, contributed to raising awareness in the cognitive and affective dimensions. On the second day, the participants were enabled to get to know each other and socialize through drama activities, and then science activities were carried out to understand the nature of disasters. In this context, disasters were explained with the nature of science from the general to the specific, from the world to Turkey. On the third day, activities involving disciplines such as mathematics, physics, geology, and engineering were performed to understand disasters. On the fourth day, disasters such as floods, deluges, overflows, and erosion were approached through the experiment, model, game, drama, and orienteering. On the fifth day, activities such as coding, body percussion, music, and modeling were held. On the sixth day, the traces of floods, deluges, overflows, landslides, erosion, and earthquakes were sought in nature on a research-examination trip. A trip to the Interactive Flood 
Ayşegül ŞEYIHOĞLU, Ayça KARTAL, Ahmet TEKBIYIK, Gülşah SEZEN VEKLI, Kader BIRINCI KONUR. The design and implementation of a teacher training program for improving teachers' disaster literacy: Interdisciplinary disaster education program (IDEP)

Museum was held, and drama-assisted museum training was provided. While the interactive museum features a virtual room where teachers can experience the moment of flooding, it also includes sections such as sediment control facility types, city flood models, landslide-flood interaction models, a flood cinema hall, a flood response room, early warning systems, and a virtual reality room in which guests feel they are immersed in the water and are instructed how to act to save themselves. On the last day, the participants designed and exhibited their interdisciplinary disaster education activities in cooperation and finally experienced the search and rescue practice in the training building. In the process, the subject of disasters was associated with the information related to fields such as social studies, science, mathematics, engineering, history, Turkish, educational sciences, Earth sciences, geography, music, sports, agricultural sciences, values education, biology, physics, chemistry, and psychology. Since disciplines such as physics, chemistry, and biology are included in science and history and geography are included in social studies, the activities were prepared in a large spectrum covering the primary school and lower secondary levels.

\section{Data Analysis}

To determine the effect of the IDEP on the natural disaster literacy levels of the participating teachers, the paired sample t-test was first conducted on the Natural Disaster Literacy Behavior and Natural Disaster Literacy Affective Tendency Scales, which were applied as the pre-testpost-test. For this test, the data were observed to meet the required assumptions of normality. Afterward, the two-way mixed ANOVA was performed to reveal the change in the improvement of the teachers' natural disaster literacy during the IDEP by their gender and branch separately. Prior to the two-way ANOVA, Mauchly's test of sphericity was conducted (Huck, 2012) for each model. If Mauchly's W was significant, the Geisser-Greenhouse conservative $F$-test was interpreted as preventive against type I error (Konnert et al., 2009).

The thematic analysis was used in the analysis of qualitative data. In this process, the sevenstep thematic analysis of Kuckartz (2014) was followed. In this scope, $20 \%$ of the data set was selected randomly and coded by the researchers. Then, the first codes were formed, and these first codes were brought together by one of the researchers. Similar and different codes were studied, and a code book was created. Afterward, the whole coding process was completed according to this code book by one of the researchers, and the themes and categories were created in the second cycle. The coding was then completed. Following the coding, two main themes (knowledge and skill dimension, activity dimension) emerged. For each main theme, sub-themes, categories, and codes were created. While creating the codes and categories, two independent researchers came together and tried to combine different codes under common statements. For example, the theme "Regarding Disasters" was changed to "Disaster Management." The categories of "Risk Management, Crisis Management, Knowledge, Solution, Awareness, Institutions" under the previously mentioned theme were changed to "Crisis Management, Knowledge Management, and Risk Management." As a result, the knowledge and skill dimension of the IDEP consisted of the themes of "Disaster Management," "Professional Development," "Skill Development," "Interdisciplinary Association," "Personal Development," and "Geographical Literacy" concerning the expectations and meeting the expectations, whereas the activity dimension was comprised of the themes of "In Terms of Process," "In Terms of Methodology," and "In Terms of Quality." In the qualitative data analysis, the data were coded by two different researchers to ensure credibility and consistency. The study participants were coded with code names (T1, T2, etc.), and no real names were used. In coding and thematization, a code book was created, the researchers rethought the codes and themes on which they agreed and disagreed, and all the codes and themes were created after taking a common decision. In this sense, the data were reviewed four times. Concerning all the themes and codes, the views of the participants were directly quoted.
PROBLEMS

OF EDUCATION

IN THE $21^{\text {st }}$ CENTURY

Vol. 79, No. 5, 2021 
Ayşegül ŞEYIHOĞLU, Ayça KARTAL, Ahmet TEKBIYIK, Gülşah SEZEN VEKLI, Kader BIRINCI KONUR. The design and implementation of a teacher training program for improving teachers' disaster literacy: Interdisciplinary disaster education program (IDEP)

PROBLEMS

OF EDUCATION

IN THE $21^{\text {st }}$ CENTURY

Vol. 79 , No. 5, 2021

790

\section{Research Results}

Effect of the IDEP on Teachers' Natural Disaster Literacy

To reveal the effect of the training program on the participating teachers' disaster literacy levels, the Natural Disaster Literacy Scale developed by Sözcü (2019) was applied as the pretest-post-test. Two subscales of this scale, which were found to be appropriate for the nature of the study, were used: The Natural Disaster Literacy Behavior and the Natural Disaster Literacy Affective Tendency sub-scales. The paired sample t-test results of the data obtained from these scales are presented in Table 3.

Table 3

The Paired Sample t-test Results Regarding the Pre-test-post-test Results of the Participating Teachers

\begin{tabular}{|c|c|c|c|c|c|c|c|c|c|}
\hline \multirow[b]{2}{*}{ Scales } & \multirow[b]{2}{*}{$n$} & \multicolumn{2}{|c|}{ Pre-test } & \multicolumn{2}{|c|}{ Post-test } & \multirow{2}{*}{$d f$} & \multirow{2}{*}{$t$} & \multirow{2}{*}{$p$} & \multirow{2}{*}{ Cohen's d } \\
\hline & & $M$ & $S D$ & $M$ & $S D$ & & & & \\
\hline $\begin{array}{l}\text { Natural Disaster } \\
\text { Literacy Behavior }\end{array}$ & 34 & 80.26 & 14.75 & 95.88 & 11.15 & 33 & -6.550 & $<.001$ & 1.195 \\
\hline $\begin{array}{l}\text { Natural Disaster } \\
\text { Literacy Affective } \\
\text { Tendency }\end{array}$ & 34 & 88.79 & 6.76 & 112.35 & 10.18 & 33 & -10.685 & $<.001$ & 2.727 \\
\hline
\end{tabular}

Upon reviewing Table 3, it was observed that the post-test averages of the teachers' natural disaster literacy behaviors $[t(33)=-6.550 ; p<.01]$ and natural disaster literacy affective tendency $[t(33)=-10.685 ; p<.01]$ increased statistically significantly compared to the pre-test. The pre-test scores of natural disaster literacy behavior increased from 80.26 to 95.88 . This increase indicated a large effect (Cohen's $d=1.195$ ). Likewise, the average scores of natural disaster literacy affective tendency increased from 88.79 to 112.35 , causing a large effect (Cohen's $d=2.727$ ).

\section{The Gender Effect}

The two-way mixed ANOVA was carried out to reveal whether this differentiation changed according to the gender of the participating teachers. The descriptive results obtained as a result of the analysis are presented in Table 4. 
Ayşegül ŞEYIHOĞLU, Ayça KARTAL, Ahmet TEKBIYIK, Gülşah SEZEN VEKLI, Kader BIRINCI KONUR. The design and implementation of a teacher training program for improving teachers' disaster literacy: Interdisciplinary disaster education program (IDEP)

Table 4

The Change in the Differentiation of the Average Scores According to the Teachers' Gender l. 79 , No. 5,202 and Branch

\begin{tabular}{|c|c|c|c|c|c|c|}
\hline \multirow{2}{*}{ Scale } & \multirow{2}{*}{ Variable } & \multicolumn{3}{|c|}{ Pre-test } & \multicolumn{2}{|c|}{ Post-test } \\
\hline & & $n$ & $M$ & $S D$ & $M$ & $S D$ \\
\hline & Gender & & & & & \\
\hline \multirow{6}{*}{$\begin{array}{l}\text { Natural Disaster } \\
\text { Literacy } \\
\text { Behavior }\end{array}$} & Female & 18 & 82.50 & 12.60 & 99.17 & 10.43 \\
\hline & Male & 16 & 77.75 & 16.92 & 92.19 & 11.09 \\
\hline & Branch & & & & & \\
\hline & Classroom & 12 & 81.17 & 14.92 & 100.00 & 10.22 \\
\hline & Science & 10 & 73.60 & 16.61 & 92.90 & 10.60 \\
\hline & Social Studies & 12 & 84.92 & 11.84 & 94.25 & 12.14 \\
\hline \multirow{7}{*}{$\begin{array}{l}\text { Natural Disaster } \\
\text { Literacy } \\
\text { Affective Tendency }\end{array}$} & Gender & & & & & \\
\hline & Female & 18 & 88.67 & 5.08 & 117.56 & 3.01 \\
\hline & Male & 16 & 88.94 & 8.44 & 106.50 & 12.20 \\
\hline & Branch & & & & & \\
\hline & Classroom & 12 & 87.67 & 6.79 & 116.42 & 4.91 \\
\hline & Science & 10 & 86.10 & 7.56 & 110.50 & 13.00 \\
\hline & Social Studies & 12 & 92.17 & 4.88 & 109.83 & 10.99 \\
\hline
\end{tabular}

In terms of the natural disaster literacy behavior, the time main effect was found to be statistically significant [Wilks' $\Lambda=.43, F(1,32)=41.39, p<.05$, partial $\eta 2=.56$ ]. However, the time by gender interaction effect was observed to be statistically insignificant [Wilks' $\Lambda=.99$, $F(1,32)=.21, p>.05$, partial $\eta 2=.00]$. Likewise, it was observed that the gender main effect did not occur at a statistically significant level $[F(1,32)=2.48, p>.05$, partial $\eta 2=.07]$ (See Figure 2 ).

\section{Figure 2}

\section{The Change in the Average Scores According to the Gender-measurement Common Effect}
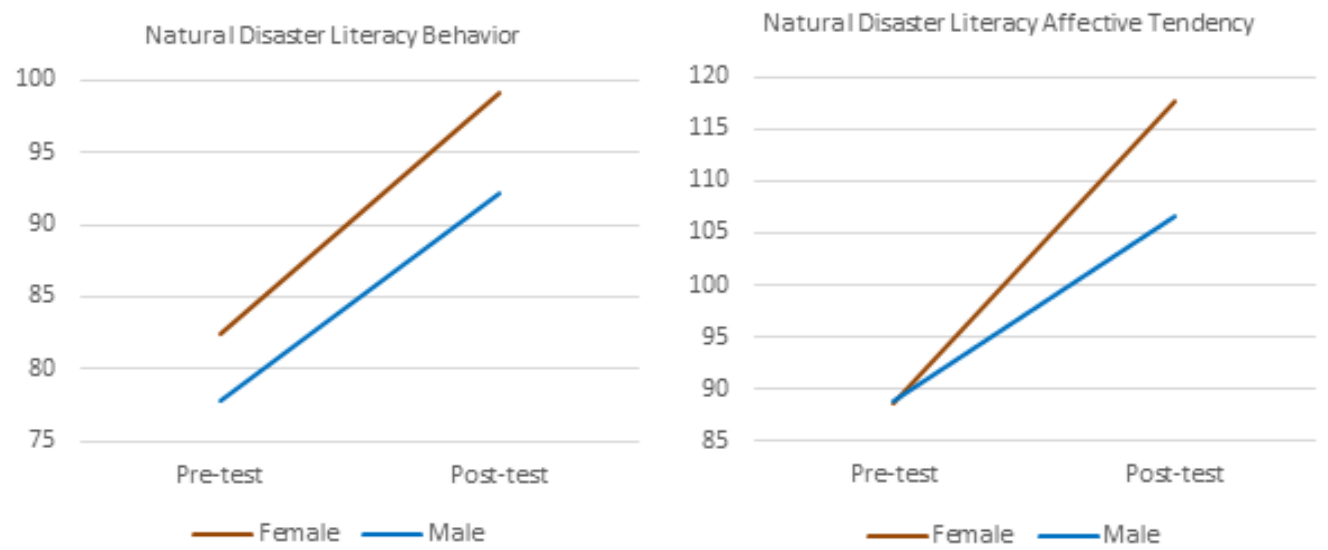

In terms of the natural disaster literacy affective tendency, the time main effect was observed to be statistically significant [Wilks' $\Lambda=.19, F(1,32)=133.90, p<.05$, partial $\eta 2=.81$ ]. On the other hand, the time by gender interaction effect was found to be statistically significant 
Ayşegül ŞEYIHOĞLU, Ayça KARTAL, Ahmet TEKBIYIK, Gülşah SEZEN VEKLI, Kader BIRINCI KONUR. The design and implementation of a teacher training program for improving teachers' disaster literacy: Interdisciplinary disaster education program (IDEP)

PROBLEMS

OF EDUCATION

IN THE $21^{\text {st }}$ CENTURY

Vol. 79, No. 5, 2021

792

[Wilks' $\Lambda=.80, F(1,32)=7.96, p<.05$, partial $\eta 2=.20]$. Likewise, it was understood that the gender main effect occurred at a significant level $[F(1,32)=9.22, p<.05$, partial $\eta 2=.22]$.

\section{The Branch Effect}

The two-way mixed ANOVA was carried out to reveal whether the average scores changed according to the branches of the participating teachers. The descriptive results obtained as a result of the analysis are presented in Table 4.

The results showed that, in terms of the natural disaster literacy behavior, the time main effect was found to be statistically significant [Wilks' $\Lambda=.40, F(1,31)=46.403, p<.05$, partial $\eta 2=.60]$. However, the time by branch interaction effect was observed to be statistically insignificant [Wilks' $\Lambda=.89, F(2,31)=2.015, p>.05$, partial $\eta 2=.12$ ]. Moreover, it was observed that the branch main effect did not occur at a significant level $[F(2,31)=1.40, p>.05$, partial $\eta 2=.08]$ (See Figure 3).

According to the analysis results, in terms of the natural disaster literacy affective tendency, the time main effect was found to be statistically significant [Wilks' $\Lambda=.20, F(1,31)=123.848$, $p<.05$, partial $\eta 2=.80]$. However, the time by branch interaction effect was observed to be statistically insignificant [Wilks' $\Lambda=.86, F(2,31)=2.460, p>.05$, partial $\eta 2=.137$ ]. Moreover, it was observed that the branch main effect did not occur at a significant level $[F(2,31)=1.21$, $p>.05$, partial $\eta 2=.07]$.

\section{Figure 3}

The Change in the Average Scores According to the Branch-measurement Common Effect
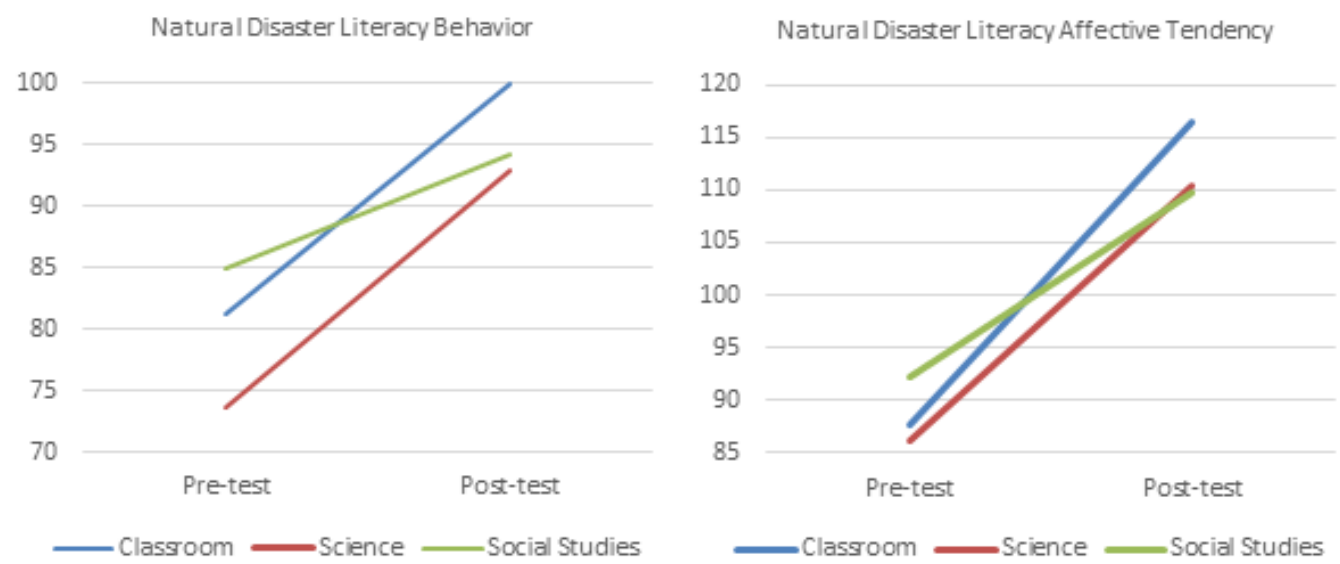

Results Regarding the Second Research Question

In this section of the study, the findings obtained from the data collection tools created with a qualitative approach are included. In this context, the teachers participating in the IDEP filled in "the expectation form" before the implementation and "the expectation fulfillment form" regarding the IDEP after its implementation. The findings obtained from these forms are presented in Figures 4 and 5. 
Ayşegül ŞEYIHOĞLU, Ayça KARTAL, Ahmet TEKBIYIK, Gülşah SEZEN VEKLI, Kader BIRINCI KONUR. The design and implementation of a teacher training program for improving teachers' disaster literacy: Interdisciplinary disaster education program (IDEP)

PROBLEMS

OF EDUCATION

IN THE $21^{\text {st }}$ CENTURY

Vol. 79, No. 5, 2021

Figure 4

793

The Model for the Participants' Expectations and the Fulfillment of their Expectations from the IDEP in the Knowledge and Skill Dimension

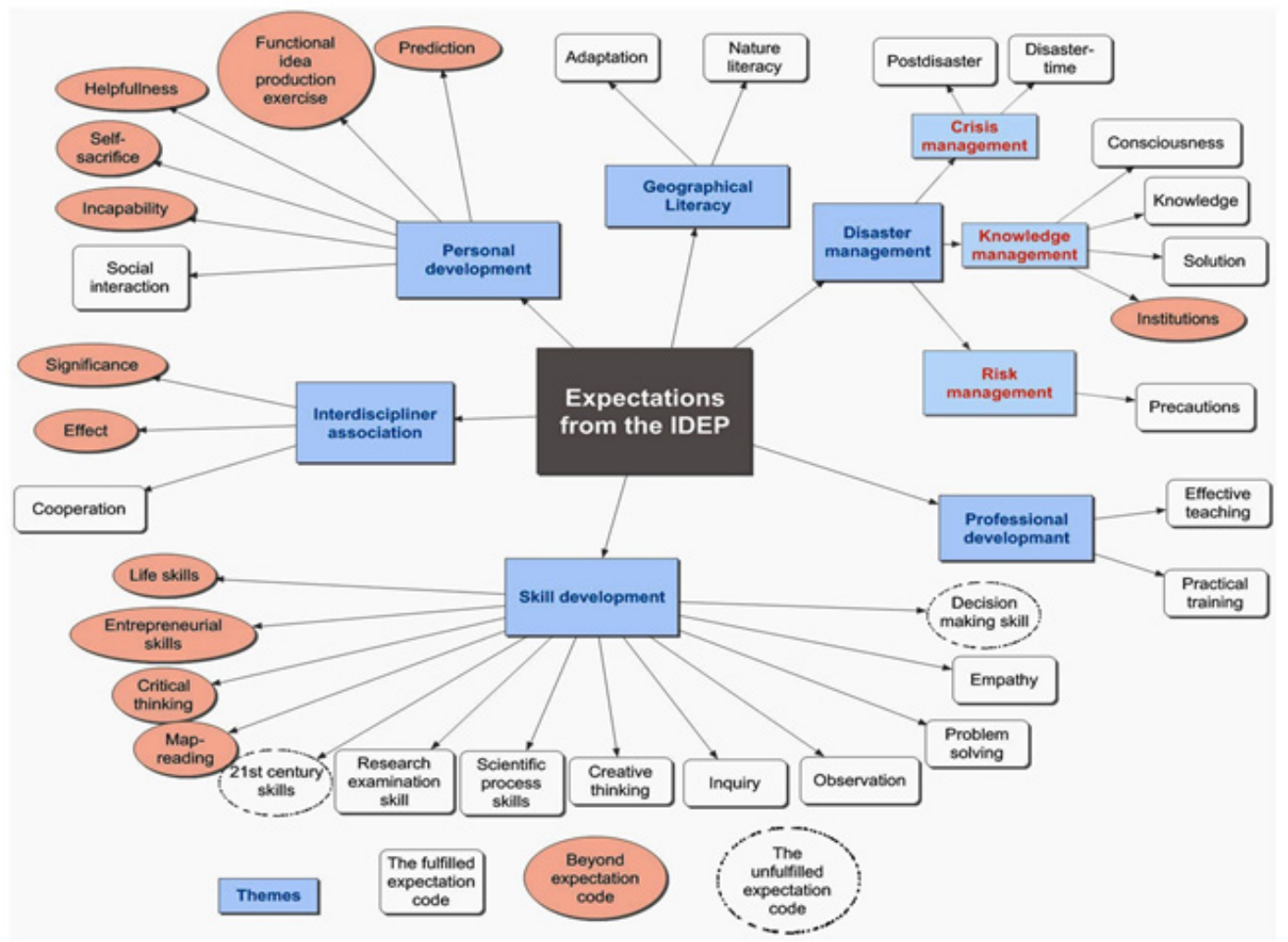

\section{Figure 5}

The Participants' Expectations and the Fulfillment of their Expectations from the IDEP in the Activity Dimension
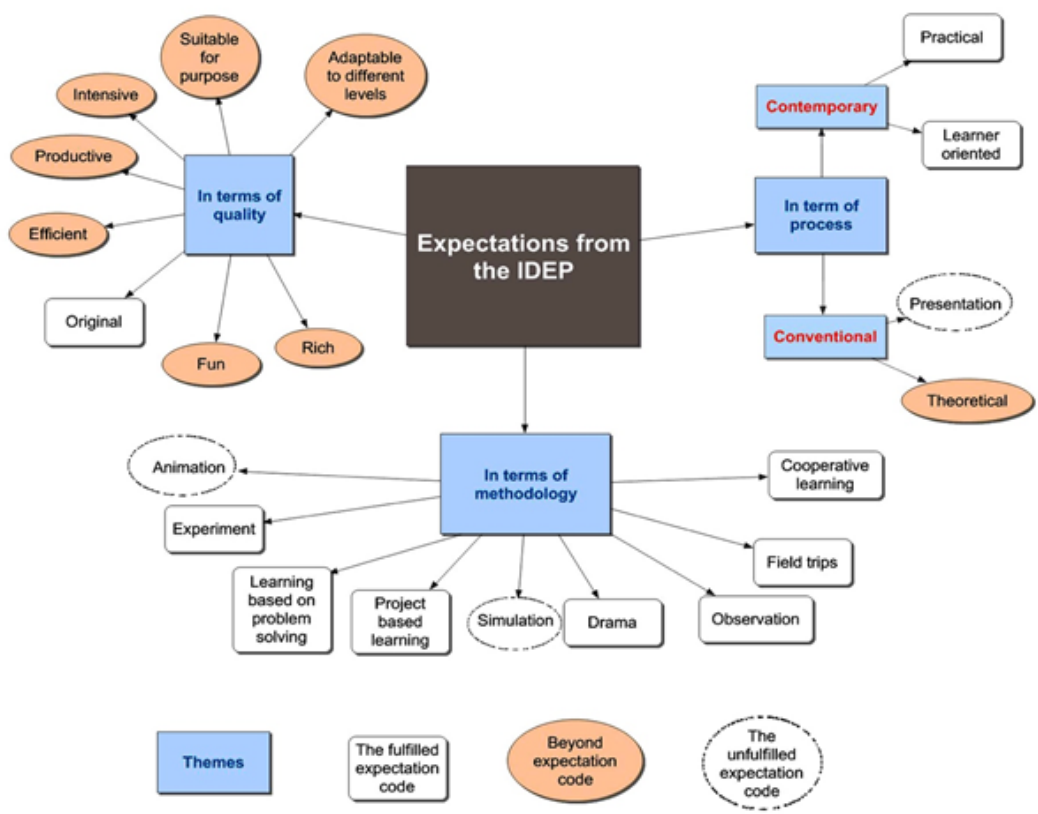
Ayşegül ŞEYIHOĞLU, Ayça KARTAL, Ahmet TEKBIYIK, Gülşah SEZEN VEKLI, Kader BIRINCI KONUR. The design and implementation of a teacher training program for improving teachers' disaster literacy: Interdisciplinary disaster education program (IDEP)

PROBLEMS

OF EDUCATION IN THE $21^{\text {st }}$ CENTURY Vol. 79, No. 5, 2021 794

The findings regarding the participants' expectations and the fulfillment of their expectations from the IDEP in the knowledge and skill dimension are presented in Figure 4. The participants' expectations on disaster-related crisis management in the knowledge and skill dimension were revealed with the post-disaster and disaster-time codes, and the relevant expectations were fulfilled.

The findings regarding the participants' expectations and the fulfillment of their expectations from the IDEP in the activity dimension are presented in Figure 5.

\section{Discussion}

In this study, regarding the first research question, the post-test averages of the natural disaster literacy behaviors and natural disaster literacy affective tendency of the teachers who participated in the training program were found to increase at a statistically significant level compared to the pre-test. This showed that the training program had a positive effect on natural disaster literacy in both behavioral and affective dimensions. In Figure 4, the fulfillment of the teachers' expectations on self-sacrifice, incapability and helpfulness in personal development and disaster-time and post-disaster knowledge, crisis and risk management are the qualitative findings supporting affective and behavioral changes. This result can be said to have been significantly affected by activities in the training program, which was implemented via interdisciplinary associations, because the program included examples of activities from various fields addressing both the behavioral (Do Your Own Design!, Design-Construct, Walk over Your Bridge in Earthquake!, What if it were You!) and affective (Wherever there is Life, there is AFAD!, IDEP Circle, Disasters in Folk Songs, etc.) characteristics of the teachers. Furthermore, the usage of different methods in this activity content may be a factor in this result. Thus, in the qualitative results, the teachers' expressions of cooperative learning, field trips, observation, drama, project-based learning, learning based on problem-solving, experiment, etc. in both expectations and expectation fulfillment supported this result.

Considering the effect of the first research question on gender, it was realized that the natural disaster literacy behaviors of the participating teachers did not differ by their gender. However, these behaviors improved at the end of the training program compared to the preprogram period. Before and after the training, an improvement was observed in the behaviors of both female and male teachers, and their behaviors were similar to each other. Furthermore, a study conducted to determine 8th-grade students' levels of understanding the concept of disaster and disaster education in the literature (Karakuş \& Önger, 2017) found that the gender variable did not affect the result in general. It was also revealed that the natural disaster literacy affective tendency of the participating teachers differed by their gender, their tendency improved after the training compared to the pre-training period, and this improvement differed by gender. The natural disaster literacy affective tendency of female teachers was similar to that of males before the training. At the end of the training, it was revealed that the tendency of both female and male teachers improved, whereas the tendency of female teachers improved more than male teachers (Figure 3a, b). In the literature, studies suggest that natural disasters affect women more than men (Neumayer \& Plümper, 2007), and female teachers find subjects related to disaster education more significant than male teachers (Buluş-Kırıkkaya et al., 2011a). This can be thought to result from the more sensitive nature of women than men when it comes to how they see events psychologically. Many studies have revealed that women give more sensitive reactions to situations with an emotional content than men (Brizendine, 2012). The limbic system, one of the emotion-related regions of the brain, is larger in women. Therefore, women are more sensitive to emotional stimulations and establish bonds more easily than men (Ruigrok et al., 2014). 
Ayşegül ŞEYIHOĞLU, Ayça KARTAL, Ahmet TEKBIYIK, Gülşah SEZEN VEKLI, Kader BIRINCI KONUR. The design and implementation of a teacher training program for improving teachers' disaster literacy: Interdisciplinary disaster education program (IDEP)

Regarding the effect of the first research question on the branch, it was concluded that the natural disaster literacy behaviors of the participating teachers did not differ by their branches, and the natural disaster literacy behaviors of the teachers from all the branches increased at similar levels before and after the training. Likewise, it was also revealed that the natural disaster literacy affective tendency of the participating teachers did not differ by their branches, and the natural disaster literacy affective tendency of the teachers from all the branches increased at similar levels before and after the training. This result may have originated from the teachers' individual views on events and evaluations made independently of their profession. Moreover, owing to the activities in the IDEP, the participating teachers may have noticed the association of their disciplines with other disciplines. The association of natural disasters as a common problem can be explained with the cooperation of teachers from every branch in the training program. It can be said that the skill, process, and methodology sections of the expectation statements in Figures 4 and 5 were related to the branches of all the participants. Therefore, no difference emerged.

Regarding the second research question, it was revealed that all the expectations on disaster education before the training were fulfilled in the knowledge and skill dimension during the IDEP. This result overlapped with the conclusion that the training had a positive, quantitative effect on the teachers' natural disaster literacy in both behavioral and affective senses. Additionally, the "Institutions" code appeared as an unexpected result (Figure 4). During the activities in the training program, the initial AFAD's introduction and then UMKE's search and rescue practice were effective in raising this awareness. Teachers' non-awareness of these institutions when they first came to the training can also be explained by the fact that this was not revealed in the expectation form applied before the training. In his study, Kundak (2018) stated that one of the ways to raise disaster awareness was the disaster experience while another one was education and raising the awareness of society of being prepared for disasters, which is a skill that can be learned, played a crucial role. The presence of the personnel who combined disaster experience with education in the training program may have increased the effect in this sense. The fact that there were AFAD workers and UMKE volunteers among the training personnel and they were together with the participants throughout the whole process may also have been effective. A study on earthquakes in the literature (Subedi et.al., 2020) reported that training activities were accepted in schools and effective in raising students' earthquake awareness, and this kind of programs should be continued. Likewise, as a result of a curriculum implemented to increase the earthquake awareness of students, significant developments were achieved in the earthquake literacy of lower secondary students (Mohadjer et al., 2010).

In the professional and skill development of the participating teachers, almost all the expectations were met with effective and practical education and teaching activities. Furthermore, it was concluded that the training program was not within the teachers' expectations but contributed to their map-reading, critical thinking, entrepreneurial and life skills, which were of great significance. On the other hand, the decision-making skill and the 21 st-century skills may look like expected but unfulfilled situations. However, it is possible to associate them with each other within entrepreneurial and life skills. It can be assumed that other expressed skills may cover these, and they can be compensated with other skills. The teachers' expectations on the decision-making skill may result from their need for first aid training and making the right and quick decision during a disaster. The statements of many teachers drew attention, suggesting that their expectations were fulfilled and even went beyond fulfillment at the end of the training. One of the significant results was the possibility of fully responding to important expectations such as empathizing, problem-solving, observation, inquiry, creative thinking, scientific process skills, and research-examination during the training program. This situation matches up with the positive conclusion from quantitative findings on the tendency to affective characteristics in natural disaster literacy. The occurrence of a flood and landslide in a close region shortly before
PROBLEMS

OF EDUCATION

IN THE $21^{\text {st }}$ CENTURY

Vol. 79, No. 5, 2021

795 
Ayşegül ŞEYIHOĞLU, Ayça KARTAL, Ahmet TEKBIYIK, Gülşah SEZEN VEKLI, Kader BIRINCI KONUR. The design and implementation of a teacher training program for improving teachers' disaster literacy: Interdisciplinary disaster education program (IDEP)

PROBLEMS

OF EDUCATION IN THE $21^{\text {st }}$ CENTURY Vol. 79 , No. 5, 2021

796

the training and their integration into the activities by educators may have affected the study in the affective dimension. A study in the literature (de Mendonca \& Valois, 2017) concluded that an emotional relationship was established with the subject when a connection was made with the real problem in the area concerning disasters. The study performed by Johnson and Ronan (2014) stated that it would be useful if teachers were well-equipped to provide students with emotional support and disaster-sensitive disaster education in society after disasters.

This training program revealed that the teachers comprehended the significance and effect of the interdisciplinary work at the end of the training. The cooperation statement expected before the training showed that they understood the necessity of performing interdisciplinary activities in cooperation by experiencing it, and this expectation was already fulfilled at the end of the training. The reason is that groups in the activities were designed heterogeneously within themselves, including teachers from every branch. The teachers' statements also indicated this situation. In Figure 5, the expression that activities ensured cooperative learning also supported it. This result can be explained by the fact that the primary purpose of this training program was not first aid but rather the implementation of the disaster education program via interdisciplinary educational activities. Studies in the literature emphasize that disaster training that requires an interdisciplinary approach should be given continuously at the primary, secondary, and higher education levels with the support of content knowledge and disaster training will be more meaningful when it includes the current education system programs and is supported by school-based disaster education and specialists (Faber et al., 2014; Gerdan, 2019; İnal et al., 2012; Mangione et al., 2013; Masterson et al., 2019; Özmen \& İnce, 2017; Zhu \& Zhang, 2017), which is consistent with this study. As a result of the training provided by De Mendonca and Valois (2017), it was demonstrated that activities based on a single discipline constituted a problem, and activities performed with an interdisciplinary approach were ideal. In their study, Turan \& Kartal, (2012) suggested an association with science in the course of Social Studies with various experiments to eliminate misconceptions on natural disasters.

It was concluded that this training program contributed to the personal development of teachers in terms of social interaction, incapability, self-sacrifice, helpfulness, functional idea production/exercise, and prediction. Most of these contributions were not among the expectations before the training program but appeared in the section of expectation fulfilment at the end of the training. This showed that the training program contributed to personal development. Moreover, there were statements indicating common situations regarding both expectations and expectation fulfillment in the nature literacy and adaptation codes.

The training program was observed to have fulfilled the teachers' expectations with the activities in its content in the practical and learner-oriented sense (Figure 5). In their study, De Mendonca and Valois (2017) stated that the landslide-related disasters course for teacher training encouraged interactive and participatory learning. While the teachers who mentioned the presence of theoretical parts in the training expected the theoretical information to be given in the form of a presentation, they encountered its integration into different methods within practical activities, which was beyond their expectations.

It was revealed that expectations on the methods used in the activities were fulfilled to a significant extent and various methods and techniques such as cooperative learning, field trips, observation, drama, project-based learning, problem-solving, and experiment were involved. Although the simulation and animation expectation was not fulfilled in the activities, other mobile applications such as coding and augmented reality, which supported this expectation, were included. The teachers who experienced the disaster simulation truck in the training had a misconception about simulation. The non-fulfillment of the animation expectation may have resulted from the weight given to learner-oriented methods far from the presentation understanding. The non-fulfillment of the presentation expectation can be considered a supportive result in this context. Furthermore, the information notes, worksheets, and info- 
Ayşegül ŞEYIHOĞLU, Ayça KARTAL, Ahmet TEKBIYIK, Gülşah SEZEN VEKLI, Kader BIRINCI KONUR. The design and implementation of a teacher training program for improving teachers' disaster literacy: Interdisciplinary disaster education program (IDEP)

graphs shared by educators with teachers before the practice can also be considered within the scope of theoretical information.

The activities came to the forefront in terms of expectation fulfillment with their qualityrelated characteristics of being rich, enjoyable, efficient, productive, intensive, suitable for the purpose, and adaptable to different levels. A study conducted with lower secondary students reported that the disaster training enriched with non-program activities had positive effects on the awareness of the relevant subjects, personal preparation for disasters, and precautions that should be taken at home (Y1lmaz, 2014). In their study, Özgen et al. (2011) emphasized that prospective teachers mostly preferred the visual learning style for learning the subject of natural disasters, and thus geography lessons with demonstrations, field studies/practices would be more efficient for students. The versatility of the activities' characteristics, as stated in the qualitative results, may have positively contributed to the teachers' natural disaster literacy levels.

When the results are evaluated in general, expectations can be said to have been fulfilled beyond the rate assumed. The high number of the codes not mentioned among the expectations but expressed within the fulfillment of the expectations at the end of the training is remarkable. This is also indicated by the teachers' statements in the findings, suggesting the over-fulfillment of the expectations. Consistent connections come to the fore between skill development and the methods used in the activities in the models presented qualitatively. In this context, the effective teaching and practical activities performed in the training program influenced the emergence of these skills and methods. This can be thought to have contributed to improving the behavior dimension of the participating teachers' disaster literacy. In the literature, Kadığlu (2008) expressed that crisis management would not be successful wherever risk management was ignored in disasters. Therefore, risk management was more important in responses to disasters. Arca (2012) asserted that not only the post-disaster response but also the pre-disaster preparations should be evaluated as a whole, and to this end, it was necessary to raise the awareness of society with disaster training programs. Şengün (2007) emphasized the importance of creating projects and programs in cooperation with various entities to reduce the damage of disasters. In summary, disaster management covers all activities needed before and after disasters (Kadığlu \& Özdamar, 2006). Buluş-Kırıkkaya et al. (2011a) suggested using more effective activities (various ready animations, field observations, etc.) outside the scope of lessons after the review of the curriculum.

\section{Conclusions and Implications}

This study reveals that the IDEP positively affected, in other words, improved the natural disaster literacy behaviors and natural disaster literacy affective tendencies of the participating teachers. Considering that educational practices are an effective tool in disaster risk reduction studies, it is observed that the current program is a viable program for gaining disaster literacy. In this context, it is thought that the activities in this program can be used in both in-school and out-of-school learning environments at primary and lower secondary school levels. In this study, the education program was developed for teachers playing a key role in all levels of primary and early secondary education. It is recommended that such interdisciplinary training programs, which are carried out with teachers to raise awareness of society in providing disaster literacy, should be carried out with other professional groups (disaster specialists, civil engineers, etc.) playing a key role, especially in disaster management.

Despite an improvement in the natural disaster literacy behaviors of the teachers participating in the IDEP after the training, it was determined that the gender and branches of the teachers did not affect their natural disaster literacy behaviors. According to another result of the study, the natural disaster literacy affective tendencies of the participating teachers also
PROBLEMS

OF EDUCATION

IN THE $21^{\text {st }}$ CENTURY

Vol. 79, No. 5, 2021 
Ayşegül ŞEYIHOĞLU, Ayça KARTAL, Ahmet TEKBIYIK, Gülşah SEZEN VEKLI, Kader BIRINCI KONUR. The design and implementation of a teacher training program for improving teachers' disaster literacy: Interdisciplinary disaster education program (IDEP)

PROBLEMS

OF EDUCATION

IN THE $21^{\text {st }}$ CENTURY Vol. 79 , No. 5,202

798

improved after the IDEP. However, it was revealed that the IDEP improved the natural disaster literacy affective tendencies of female teachers more than male teachers. In the current study, the effect of the IDEP on natural disaster literacy behavior and affective tendencies, as well as the effect of teachers' gender and branches on this variable, was examined. Other researchers working in the field of disaster education can examine the effects of the current program on the natural disaster literacy behaviors and affective tendencies of different factors such as the disaster experience of teachers, the disaster risk potential in the region of their residence, and their professional experience.

According to another result obtained from the study, since the participating teachers in the IDEP were in anticipation of their professional knowledge and skill development, it taught teachers many skills such as problem-solving, observation, questioning, creative thinking, scientific process skills, research and examination through applied education and training activities. The increase in the number of disasters and the loss of life and property in these disasters, both in Turkey and globally, has revealed the need to address the issue with increasing importance. It is recommended that different approaches, models, and practices in disaster education be evaluated in comparison with each other and applied training with high impact levels be disseminated. It can also be ensured that documents related to this training can be compiled and, if necessary, published in books and shared on platforms that teachers and students can reach more easily.

\section{Limitations}

This study had some limitations since it aimed to design a disaster education program for teachers and determine its effects on teachers. The IDEP was designed for science, classroom, and social studies teachers who were expected to deal with issues related to disaster education at primary and lower secondary school levels. Thirty-six teachers participated in the IDEP activities (4x9 or 6x6), designed as group work of four or six people. Thus, nine or six groups took part in each activity. Therefore, the sample of the study was limited to 36 teachers.

The scope of the activities discussed in the study was limited to earthquakes, floods, deluges, overflows, landslides, and erosions. The lack of activities related to fire, tornado, or man-made disasters was another limitation. The IDEP activities were implemented face-toface in September 2020, the period included in the COVID-19 pandemic. Since there was no vaccination in Turkey at that time, training was carried out by taking COVID-19 pandemic measures. Especially mask, social distancing, and hygiene rules were complied with, which may have affected the motivation of the participants in group activities.

\section{Acknowledgments}

This study was supported by the Scientific and Technological Research Council of Turkey (TÜBİTAK; Project number: 119B164)

\section{References}

AFAD. National Earthquake Strategy and Action Plan 2012-2023. Prime Ministry Disaster and Emergency Management Presidency. http://www.deprem.gov.tr/sarbis/Doc/

Akbulut, M., \& Kaya, A. (2020). The investigation of global climate change as a disaster and the global climate change awareness of primary school teachers: Sample of Gümüşhane Province. Gümüşhane University Journal of Health Science, 9(2), 112 124. https://doi.org/10.37989/gumussagbil.700929 
Ayşegül ŞEYIHOĞLU, Ayça KARTAL, Ahmet TEKBIYIK, Gülşah SEZEN VEKLI, Kader BIRINCI KONUR. The design and implementation of a teacher training program for improving teachers' disaster literacy: Interdisciplinary disaster education program (IDEP)

Arca, D. (2012). Geographic information system and remote sensing in disaster management. Karaelmas Science and Engineering Journal, 2(2), 53-61. https://dergipark.org.tr/tr/pub/karaelmasfen/ issue $/ 57130 / 806051$

Baytiyeh, H. (2018). Can disaster risk education reduce the impacts of recurring disasters on developing societies? Education and Urban Society, 50(3), 1-16. https://doi.org/10.1177/0013124517713111

Brizendine, L. (2012). Female brain. Say Publications.

Brown, L. M., Haun, J. N., \& Peterson, L. (2014). A proposed disaster literacy model. Disaster Medicine and Public Health Preparedness, 8(3), 267-275. https://doi.org/10.1017/dmp. 2014.43

Buluş-Kırıkkaya, E., Çakın, O., İmalı, B., \& Bozkurt, E. (2011a). Earthquake training is gaining importance: the views of 4th and 5th year students on Earthquake. Procedia Social and Behavioral Sciences, 15, 2305-2313. https://doi.org/10.1016/j.sbspro.2011.04.098

Buluş-Kırıkkaya, E., Oğuz-Ünver, A., \& Çakın, O. (2011b). Teachers views on the topic of disaster education at the field on elementary science and technology curriculum. Necatibey Faculty of Education Electronic Journal of Science and Mathematics Education, 5(1), 24-42. https://dergipark.org.tr/tr/pub/balikesirnef/issue/3372/46534

Cabilao-Valencia, M. I., Ali., M., Maryani, E., \& Supriatna, N. (2018). Integration of disaster risk reduction in the curriculum of Philippine Educational Institution. Advances in Social Science, Education and Humanities Research, 253. https://download.atlantis-press.com/proceedings/aes$18 / 55917397$

Chung, S. C., \& Yen, C. J. (2016). Disaster prevention literacy among school administrators and teachers: a study on the plan for disaster prevention and campus network deployment and experiment in Taiwan. Journal of Life Sciences, 10, 203-214. https://doi.org/10.17265/1934-7391/2016.04.006

Cin, M. (2010). Prospective classroom teachers' misconceptions about natural hazards. Marmara Journal of Geography, 22, 70-81. https://dergipark.org.tr/tr/pub/marucog/issue/469/3790

Creswell, J. W., \& Plano Clark, V. L. (2015). Mixed method research design and implementation. (Y. Dede \& S. B. Demir, Transl. Ed.). Anı Publishing.

Çalışkan, C. (2020). Disaster literacy scale development study [Unpublished Doctoral dissertation]. Hacettepe University Institute of Health Sciences. http://www.openaccess.hacettepe.edu.tr:8080/ xmlui/bitstream/handle/11655/22296/10213916..pdf? sequence $=5 \&$ isAllowed $=y$

Das, T. K. (2011). An interdisciplinary study of natural disasters. In T. K. Das, I. Das Gupta, D. Lohar and B. Bhattacharya (Eds.), Disasters in west Bengal: An interdisciplinary study (pp. 1-6). ACB Publications. https://ssrn.com/abstract=1933446

Değirmenci, Y. (2019). An examination of metaphors regarding the concept of natural disaster developed by prospective classroom teachers. International Journal of Geography and Geography Education, 39, 83-94. https://doi.org/10.32003/iggei.488627

De Mendonca, M. B., \& Valois, A. S. (2017). Disaster education for landslide risk reduction: An experience in a public school in Rio de Janeiro State, Brazil. Natural Hazards, 89, 351-365. https://doi.org/10.1007/s11069-017-2968-2

Demirdelen, S. (2018). Determination of natural disaster literacy levels of primary/secondary teachers working in Osmaniye province. [Unpublished Master Thesis]. Gümüşhane University. https://tez.yok.gov.tr/UlusalTezMerkezi/tezSorguSonucYeni.jsp

Faber, M H., Giuliani, L., Revez, A., Jayasena, S., Sparf, J., \& Mendez, J. M. (2014). Interdisciplinary approach to disaster resilience education and research. Procedia Economics and Finance, 18, 601-609.

Gerdan, S. (2019). Disaster trainings as a social responsibility field. International Journal of Management and Administration, 3(5), 101-110. https://doi.org/10.29064/ijma.523265

Gökmenoğlu, T., Sönmez, E.D., Yavuz, I. \& Gök, A. (2020). Turkish ministry of national education schoolbased disaster education program: Preliminary results of the program evaluation. International Journal of Disaster Risk Reduction, 1-8. https://doi.org/10.1016/j.ijdrr.2020.101943

Huck, S. W. (2012). Reading statistics and research (6th Ed). Pearson.

IFRC. (2020). World disasters report, come heat or high water, international federation of red cross and red crescent societies. Geneva.

Işık, Ö., Özer, N., Sayın, N., Mishal, A., Gündoğdu, O., \& Özçep, F. (2015). Are women in Turkey both risks and resources in disaster management. International Journal of Environmental Research and Public Health, 12, 5758-5774. https://doi.org/10.3390/ijerph120605758

\section{PROBLEMS \\ OF EDUCATION \\ IN THE $21^{\text {st }}$ CENTURY \\ Vol. 79, No. 5, 2021}


Ayşegül ŞEYIHOĞLU, Ayça KARTAL, Ahmet TEKBIYIK, Gülşah SEZEN VEKLI, Kader BIRINCI KONUR. The design and implementation of a teacher training program for improving teachers' disaster literacy: Interdisciplinary disaster education program (IDEP)

PROBLEMS

OF EDUCATION IN THE $21^{\text {st }}$ CENTURY Vol. 79 , No. 5, 2021

800

İnal, E., Kocagöz, S., \& Turan, M. (2012). Basic disaster consciousness and preparation levels. Turkish Journal of Emergency Medicine, 12(1), 15-19. https://doi.org/10.5505/1304.7361.2012.05658

Jacobs, H. H. (1989). Design options for integrated curriculum. H. H. Jacobs (Ed.), In Interdisciplinary curriculum: Design and Implementation (pp. 13-24). Association for Supervision and Curriculum Development.

Johnson, V. A., \& Ronan, K. R. (2014). Classroom responses of New Zealand school teachers following the 2011 Christchurch earthquake. Natural Hazards, 72, 10751092. https://doi.org/10.1007/s11069-014-1053-3

Jones, J. L., Rotabi, K. S., Levy, J. K., \& Gray, L. A. (2012). An interdisciplinary approach to developing innovative teaching strategies for responding to global disasters. Advances in Social Work, 13(2), 279-290. https://journals.iupui.edu/index.php/advancesinsocialwork/issue/view/210/27

Kadıŏlu, M. (2008). Basic principles of disaster mitigation (1st. Edition). JICA Turkey Office Publications.

Kadığlu, M., \& Özdamar, E. (Eds). (2006). Basic principles of disaster management. JICA Turkey Office Publications.

Kanbara, S., Ozawa, W., Ishimine, Y., Ngatu, N. R., Nakayama, Y., \& Nojima, S. (2016). Operational definition of disaster risk-reduction literacy. Health Emergency and Disaster Nursing, 3, 1-8. https://www.jstage.jst.go.jp/article/hedn/3/1/3 2014-0016/_pdf/-char/en

Karabulut, D., \& Bekler, T. (2019). Effects of natural disasters on children and adolescents. Journal of Natural Hazards and Environment, 5(2), 368-376. https://doi.org/10.21324/dacd.500356

Karakuş, U., \& Önger, S. (2017). Levels on natural disasters and disasters education concepts for 8th grade students. Journal of History Culture and Art Research, 6(6), 482-491. http://dx.doi.org/10.7596/ taksad.v6i6.1247

Kimura, R., Hayashi, H., Kobayashi, K., Nishino, T., Kenshin, U., \& Satoshi, I. (2017). Development of a disaster management literacy hub for collecting, creating, and transmitting disaster management content to increase disaster management literacy. Journal of Disaster Research, 12(1), 42-56. https://doi.org/10.20965/jdr.2017.p0042

Koç, H., Şeker, G., Evci, N., \& Doğan, M. (2020). Evaluation of disaster education research by content analysis method. Cumhuriyet International Journal of Education, 9(2), 637-655. http://dx.doi.org/10.30703/cije.679526

Konnert, C., Dobson, K., \& Stelmach, L. (2009). The prevention of depression in nursing home residents: A randomized clinical trial of cognitive-behavioral therapy. Aging and Mental Health, 13(2), 288 299. https://doi.org/10.1080/13607860802380672

Kuckartz, U. (2014). Qualitative text analysis a guide to methods, practice and using software. SAGE Publications.

Kundak, S. (2018). Cities, disasters and people. http://dosya.toprakisveren.org.tr/makale/2011-92sedakundak.pdf

Lin, C. K., Nifa, F. A. A., Musa, S., Shahron, S. A., \& Anuar, N. A. (2018). Challenges and opportunities of disaster education program among UUM student. Proceedings of the 3rd International Conference on Applied Science and Technology (ICAST'18). https://doi.org/10.1063/1.5055440

Mangione, G. R., Capuano, N., Orciuoli, F., \& Ritrovato, P. (2013). Disaster education: A narrative-based approach to support learning, motivation, and students' engagement. Journal of e-Learning and Knowledge Society, 9(2), 129-152.

Masterson, J., Meyer, M., Ghariabeh, N., Hendricks, M., Lee, RJ., Musharrat, S., Newman, G., Sansom, G., \& Zandt, S. V. (2019). Interdisciplinary citizen science and design projects for hazard and disaster education. International Journal of Mass Emergencies and Disasters, 37(1), 6-24. https://www.ncbi.nlm.nih.gov/pmc/articles/PMC6594559/

Mata-Lima, H., Alvino-Borba, A., Pinheiro, A., Mata-Lima, A., \& Almeida, J. A. (2013). Impacts of natural disasters on environmental and socio-economic systems: what makes the difference? Ambiente \& Sociedade, 16(3), 45-64. https://www.scielo.br/j/asoc/a/ b8D9BKhQXYsKhR3X7Lnsxfm/?lang=en\&format=pdf

Miller, R. (2005). Philosophical sources of holistic education. Journal of Values Education, 3(10), 35-42. https://journals.indexcopernicus.com/search/article?articleId=2348550

Mustadi, A., \& Atmojo, S. E. (2020). Student's disaster literation in 'SETS' (science environment technology and society) disaster learning. Elementary Education Online, 19(2), 667-678. https://doi.org/10.17051/ilkonline.2020.693118 
Ayşegül ŞEYIHOĞLU, Ayça KARTAL, Ahmet TEKBIYIK, Gülşah SEZEN VEKLI, Kader BIRINCI KONUR. The design and implementation of a teacher training program for improving teachers' disaster literacy: Interdisciplinary disaster education program (IDEP)

Mohadjer, S., Bendick, R., Halvorson, S. J., Saydullaev, U., Hojiboev, O., Stickler, C., \& Adam, Z. R. (2010). Earthquake emergency education in Dushanbe, Tajikistan. Journal of Geoscience Education, 58(2), 86-94. https://doi.org/10.5408/1.3534854

Neumayer, E., \& Plümper, T. (2007). The gendered nature of natural disasters: the impact of catastrophic events on the gender gap in life expectancy 1981-2002. Annals of the Association of American Geographers, 97(3), 551-566. https://doi.org/10.1111/j.1467-8306.2007.00563.x

Nifa, A. A. A., Abbas, S. R., Lin, C. K., \& Othman, S. N. (2017). Developing a disaster education program for community safety and resilience: The preliminary phase. The 2nd International Conference on Applied Science and Technology (ICAST'17). https://doi.org/10.1063/1.5005338

Okay, N., \& İlkkaracan, İ. (2018). Gender sensitive disaster risk management. Journal of Resilience, 2(1), 1-12. https://doi.org/10.32569/resilience.431075

Öcal, A., Yıldırım, E., Yakar, H., \& Erdoğan, E. (2016). Examination of social studies prospective teachers' beliefs on disasters. Kırlkkale University Journal of Social Sciences, 6(2), 59-72. https://dergipark.org.tr/tr/pub/kusbd/issue/25163/265817

Özgen, N., Eser-Ünald, Ü., \& Bindak, R. (2011). Determining the teacher candidates' "effective learning styles" on natural disasters. Ahi Evran University Journal of Kirşehir Education Faculty, 12(4), 303-323. https://kefad2.ahievran.edu.tr/archieve/pdfler/Cilt12Sayi4/JKEF_12_4_2011_303-323. pdf

Özmen, B., \& İnce, ZD. (2017). School based disaster education. Journal of Resilience, 1(1), 21-29. https://doi.org/10.32569/resilience.356892

Panić, M., Kovačević-Majkić, J., Miljanović, D., \& Miletić, R. (2013). Importance of natural disaster education - case study of the earthquake near the city of Kraljevo. Journal of the Geographical Institute "Jovan Cvijic", 63(1), 75-88. http://www.doiserbia.nb.rs/Article.aspx?ID=035075991300001P\#.YArI8S3Ok_E

Pascapurnama, D. N., Murakami, A., Chagan-Yasutan, H., Hattori, T., Sasaki, H., \& Egawa, S. (2018). Integrated health education in disaster risk reduction: Lesson learned from disease outbreak following natural disasters in Indonesia. International Journal of Disaster Risk Reduction, 29, 94-102. https://doi.org/10.1016/j.ijdrr.2017.07.013

Priyowidodo, G., \& Luik, J. E. (2013). Communicating disaster mitigation literacy to coastal communities in Pacitan Indonesia [Doctoral dissertation]. Petra Christian University. http://repository.petra. ac.id/16596/

Rahim, N. B. A., \& Wu, B. S. (2015). Disaster prevention literacies: assessing the knowledge, skills and attitude of Taiwanese students for an earthquake disaster. https://www.hsseonline.edu.sg/sites/ default/files/uploaded/journal_articles/6Disaster\%20educationv1.pdf

Ruigrok, A. N. V., Salimi-Khorshidi, G., Lai, M. C., Baron-Cohen, S., Lombardo, M. V., Tait, R. J., \& Suckling, J. (2014). A meta-analysis of sex differences in human brain structure. Neuroscience \& Biobehavioral Reviews, 39, 34-50. https://doi.org/10.1016/j.neubiorev.2013.12.004

Sampurna, P. J., Sarı, Y. A., \& Wijaya, A. D. (2015). Integrating stem (science, technology, engineering, mathematics) and disaster (stem) education for building students' disaster literacy. International Journal of Learning and Teaching, 1(1), 73-76. http://www.ijlt.org/ uploadfile/2015/0826/20150826095112837.pdf

Selby, D., \& Kagawa, F. (2012). Disaster risk reduction in school curricula: case studies from thirty countries. United Nations Children Fund UNICEF.

Sözcü, U. (2019). Determining natural disaster literacylevels of preservice teachers [Doctoral dissertation]. Kastamonu University. https://tez.yok.gov.tr/UlusalTezMerkezi/tezSorguSonucYeni.jsp

Sözcü, U. (2020). Natural disaster literacy curriculum proposal. Journal of Disaster and Risk, 3(1), 7079. https://dergipark.org.tr/en/download/article-file/1089450

Sözcü, U., \& Aydınözü, D. (2019). Examining the natural disaster literacy levels of pre-service teachers according to some variables. International Journal of Geography and Geography Education (IGGE), 40, 79-91. https://doi.org/10.33902/JPR.2021270164

Subedi, S., Hetényi, G., \& Shackleton, R. (2020). Impact of an educational program on earthquake awareness and preparedness in Nepal. Geoscience Communication, 3(2), 279-290, https://doi.org/10.5194/gc-3-279-2020

Şengün, H. (2007). Studies of the Ministry of Public Works and Settlement in the Marmara earthquake and legal issues. Disaster Symposium, Ankara.
PROBLEMS

OF EDUCATION

IN THE $21^{\text {st }}$ CENTURY

Vol. 79, No. 5, 2021 
Ayşegül ŞEYIHOĞLU, Ayça KARTAL, Ahmet TEKBIYIK, Gülşah SEZEN VEKLI, Kader BIRINCI KONUR. The design and implementation of a teacher training program for improving teachers' disaster literacy: Interdisciplinary disaster education program (IDEP)

PROBLEMS

OF EDUCATION IN THE $21^{\text {st }}$ CENTURY Vol. 79 , No. 5, 2021

Şeyihoğlu A., \& Duman, N. (2019). Emergency and disaster coordination senters. In R. Sever (Ed.), Disaster and disaster management (pp. 325-346), Pegem Academy Publishing.

Pincha, C. (2009). Gender sensitive disaster management: a toolkit for practitioners (D. Keskin, Demirer, Trans.). Kocaeli University Publications.

Taubenbock, H., Goseberg, N., Setiadi, N., Lammel, G., Moder, F., Oczipka, M., Klupfel, H., Wahl, R., Schlurmann, T., Strunz, G., Birkmann, J., Nagel, K., Siegert, F., Lehmann, F., Dech, S., Gress, A., \& Klein, R. (2009). "Last-Mile" preparation for a potential disasterInterdisciplinary approach towards tsunami early warning and an evacuation information system for the coastal city of Padang, Indonesia. National Hazards and Earth System Science, 9,1509-1528. http://dx.doi.org/10.5194/nhess-9-1509-2009

Torani, S., Majd, P. M., Maroufi, S. S., Dowlati., M., \& Sheikhi, R. A. (2019). The importance of education on disasters and emergencies: A review article. Journal of Education and Health Promotion, 8(85), 1-7. https://www.jehp.net/temp/JEduHealthPromot8185-3174499_084904.pdf

Turan, İ. \& Kartal, A. (2012). The misconcepts of the fifth grade students on natural disasters. Ahi Evran University Kırşehir Journal of Education Faculty, 13(3), 67-81. https://www.researchgate. net/publication/335910079_The_Misconcepts_Of_The_Fifth_Grade_Students_On_Natural Disasters

Türkan, H., \& K1lıç, I. (2017). A description on cognitive, affective and behavioral dimensions of attitudes of university students towards disasters. Journal of the Human and Social Sciences Researches 6(1), 114-127. http://www.itobiad.com/tr/download/article-file/317092

UN Beijing Declaration (1995). Beijing declaration and platform for action the fourth world conference on women. 4-15 September, Beijing. https:/www.un.org/en/events/pastevents/pdfs/Beijing Declaration_and_Platform_for_Action.pdf

Ünal, S. (2019). The role of education in civil engineering natural disaster reduction in Turkey. [Master Thesis]. Beykent University. https://tez.yok.gov.tr/UlusalTezMerkezi/tezSorguSonucYeni.jsp

Vaughter, P. (2016). Unmaking disasters: education as a tool for disaster response and disaster risk reduction. United Nations University Institute for the Advanced Study of Sustainability (UNUIAS). https://collections.unu.edu/eserv/UNU:5705/PB6.pdf

Yazıc1, Ö., \& Ulu-Kalın, Ö. (2018). A comparative analysis of conceptual metaphors for "natural disaster". e-Kafkas Journal of Educational Research, 5(1), 25-40. https://doi.org/10.30900/kafkasegt.396396

Y1lmaz, E. (2014). School-based disaster education through curricular and extra-curricular activities: a comparative case study [Master Thesis]. Middle East Technical University. https://tez.yok.gov.tr/ UlusalTezMerkezi/tezSorguSonucYeni.jsp

Zhu, T. T., \& Zhang, Y. J. (2017). An investigation of disaster education in elementary and secondary schools: evidence from China. Natural Hazards, 89, 1009-1029. https://doi.org/10.1007/s11069-017-3004-2

\section{Appendix. Survey questions about the IDEP expectations and meeting expectations}

\begin{tabular}{|c|c|}
\hline IDEP Initial survey questions & IDEP Final survey questions \\
\hline $\begin{array}{l}\text { 1. An Innovative Approach in Disaster Education: } \\
\text { What kind of knowledge do you hope to acquire in the } \\
\text { teacher training program called the Interdisciplinary } \\
\text { Disaster Education Program (IDEP)? } \\
\text { 2. An Innovative Approach in Disaster Education: What } \\
\text { kind of skills do you hope to acquire in the teacher } \\
\text { training program called the Interdisciplinary Disaster } \\
\text { Education Program (IDEP)? } \\
\text { 3. An Innovative Approach in Disaster Education: } \\
\text { What kind of activities do you expect to encounter } \\
\text { in the teacher training program called the } \\
\text { Interdisciplinary Disaster Education Program } \\
\text { (IDEP)? }\end{array}$ & $\begin{array}{l}\text { 1. What kind of knowledge have you acquired in the } \\
\text { teacher training program called the Interdisciplinary } \\
\text { Disaster Education Program (IDEP)? } \\
\text { 2. What kind of skills have you acquired in the teacher } \\
\text { training program called the Interdisciplinary Disaster } \\
\text { Education Program (IDEP)? } \\
\text { 3. What kind of activities have you encountered in the } \\
\text { teacher training program called the Interdisciplinary } \\
\text { Disaster Education Program (IDEP)? }\end{array}$ \\
\hline
\end{tabular}


Ayşegül ŞEYIHOĞLU, Ayça KARTAL, Ahmet TEKBIYIK, Gülşah SEZEN VEKLI, Kader BIRINCI KONUR. The design and implementation of a teacher training program for improving teachers' disaster literacy: Interdisciplinary disaster education program (IDEP)

\begin{tabular}{|c|c|}
\hline Ayşegül Şeyihoğlu & $\begin{array}{l}\text { PhD, Professor, Department of Geography Education, Trabzon University, } \\
\text { Trabzon, Turkey. } \\
\text { E-mail: aseyihoglu@trabzon.edu.tr } \\
\text { ORCID: https://orcid.org/0000-0001-8143-3753 }\end{array}$ \\
\hline Ayça Kartal & $\begin{array}{l}\text { PhD, Associate Professor, Department of Primary Education, Muş } \\
\text { Alparslan University, Muş, Turkey. } \\
\text { E-mail: a.kartal@alparslan.edu.tr } \\
\text { ORCID: https://orcid.org/0000-0002-4297-8002 }\end{array}$ \\
\hline Ahmet Tekbiyik & $\begin{array}{l}\text { PhD, Associate Professor, Department of Mathematics and Science } \\
\text { Education, Kahramanmaras Sutcu Imam University, Kahramanmaras, } \\
\text { Turkey. } \\
\text { E-mail: atekbiyik@gmail.com } \\
\text { ORCID: https://orcid.org/0000-0001-7759-3121 }\end{array}$ \\
\hline $\begin{array}{l}\text { Gülşah Sezen Vekli } \\
\text { (Corresponding author) }\end{array}$ & $\begin{array}{l}\text { PhD, Associate Professor, Department of Mathematics and Science } \\
\text { Education, Yozgat Bozok University, Yozgat, Turkey. } \\
\text { E-mail: gulsahsezen28@gmail.com } \\
\text { ORCID: https://orcid.org/0000-0003-3367-3706 }\end{array}$ \\
\hline Kader Birinci Konur & $\begin{array}{l}\text { PhD, Associate Professor, Department of Mathematics and Science } \\
\text { Education, Recep Tayyip Erdogan University, Rize, Turkey. } \\
\text { E-mail: kader.konur@erdogan.edu.tr } \\
\text { ORCID: https://orcid.org/0000-0003-0766-5585 }\end{array}$ \\
\hline
\end{tabular}

